\title{
The mysterious case of the successful appeal and the missing costs award: Competition and Markets Authority v. Flynn Pharma Limited
}

\author{
Sophie Lawrance* and Aimee Brookes ${ }^{\dagger}$
}

\begin{abstract}
In May 2020 the Court of Appeal gave judgment in Competition and Markets Authority v. Flynn Pharma and Pfizer, which adjusted the starting point for costs awards following successful appeals of Competition and Markets Authority decisions. Following this judgment, such awards by the Competition Appeal Tribunal must start from the position that no order as to costs should be made against the CMA, rather than the standard approach of 'costs follow the event' that had been the CAT's established practice. This article examines the rationale for the CAT's past practice, the basis for the Court of Appeal's judgment altering that approach, and considers the potential implications the judgment may have.
\end{abstract}

Keywords: costs, appeals of CMA infringement decisions, competition policy, Competition and Markets Authority (CMA), Competition Appeal Tribunal (CAT)

\section{Introduction}

In May 2020 the Court of Appeal gave judgment in Competition and Markets Authority v. Flynn Pharma and Pfizer ${ }^{1}$ on the costs to be awarded in proceedings following a partially successful appeal by Flynn Pharma and Pfizer against the Competition and Markets Authority (CMA) decision concerning the pricing of phenytoin sodium capsules in the UK. ${ }^{2}$

The Court of Appeal considered the appropriate starting point to be used by the Competition Appeal Tribunal (CAT), which hears appeals against CMA decisions, when assessing the costs to be awarded in the event of an (at least partially) successful appeal against a competition authority decision. Despite an established practice in competition appeals of using the standard approach in civil cases that 'costs follow the event', the Court of Appeal's judgment means that the CAT must now start from the standard position that no order as to costs should be made against the CMA, unless there is good reason to do so: the mere fact that the appeal succeeds is not sufficient reason in itself.

This article describes the Court of the Appeal's reasoning, as well as the relevant background, and discusses the possible implications of this change in approach.

\section{Background}

In December 2016, following an investigation that had by that stage lasted over three and a half years, the CMA issued an infringement decision to Pfizer Limited and Pfizer Inc (together Pfizer), and Flynn Pharma Limited and Flynn Pharma (Holdings) Limited (together Flynn) finding that each had abused its respective dominant position by charging excessive prices in the UK for phenytoin sodium capsules. Excessive pricing is usually viewed as a difficult abuse to establish, and there is limited case law to guide the parties as to where the bright lines between excessive and non-excessive prices lie. 
The Phenytoin decision was the CMA's first in this area, ${ }^{3}$ but at the time it was made, it had opened two further excessive pricing investigations in relation to the pharmaceutical sector. ${ }^{4}$

Both Pfizer and Flynn appealed to the CAT, and in June 2018 the CAT found that both held dominant positions but, finding that the CMA had erred in a number of respects, remitted the question of abuse back to the CMA. ${ }^{5}$ The CMA, Pfizer and Flynn all sought to appeal the CAT's judgment, and permission was granted to Flynn and the CMA by the Court of Appeal in December 2018. At around the same time the parties filed written submissions with the CAT on costs. The CAT gave its costs ruling in March 2019, but stayed the order pending the outcome of the proceedings in the Court of Appeal. ${ }^{6}$ The CMA also appealed the costs ruling to the Court of Appeal.

On 10 March 2020 the Court of Appeal handed down its judgment on the substantive case. ${ }^{7}$ The CAT's remittal of the case back to the CMA to reconsider the issue of abuse was upheld, with the Court of Appeal clarifying the legal test to be applied in finding an abuse by excessive pricing and the extent of the CMA's duty to investigate. ${ }^{8}$ The Court of Appeal gave judgment on the costs questions on 12 May 2020..$^{9}$ Although the particular context (involving a remittal of a CMA decision, in circumstances in which a number of the CMA's arguments were accepted by the Court of Appeal) is rather specific, the judgment of the Court of Appeal is far-reaching, with implications for all appeals of CMA infringement decisions, including those which more conclusively quash the CMA's decision.

Before reviewing the Court of Appeal's costs judgment, below we first consider the general context in which appeals of CMA infringement decisions arise, and explain the approach to costs adopted by the CAT at first instance in this case.

\section{The importance of appeals in competition law}

CMA infringement decisions can seriously affect those to whom they are directly addressed, often involving large financial penalties, behavioural orders (akin to mandatory or prohibitory injunctions) or, more rarely, the restructuring of a business. Competition authority investigations and the resultant sanctions are recognized as being equivalent to criminal penalties, engaging the protections available under the European Convention on Human Rights for the companies involved..$^{10}$ Increasingly, individual directors are being sanctioned by the CMA through the use of its director disqualification powers, alongside the risk of criminal proceedings against individuals. Competition infringement decisions can also be a springboard for private damages actions, with the decision - once all rights of appeal have been exhausted or expired - satisfying the fundamental elements (in a claim for breach of statutory duty) of existence and breach of duty, leaving only causation and quantum remaining to be determined.

The implications of such decisions are therefore significant. Nevertheless, it has always been the case that companies have to bear their own legal costs of responding to an investigation (whether as a party under investigation or a third party), and that such costs cannot be recovered even if the CMA ultimately closes the investigation or concludes that there are no grounds for action.

As with other rulings interpreting broadly applicable legal concepts, a CMA infringement decision also has implications for the wider business community: other companies engaging in similar commercial activities to the addressees will also need to take due account of CMA decisions, in particular where these address novel forms of conduct (e.g. those resulting from new ways of doing business which have not previously been
3 The Office of Fair Trading had previously held that Napp Pharmaceutical had engaged in both excessive and predatory pricing in relation to sustained release morphine, a decision which was upheld on appeal to the Competition Commission Appeal Tribunal: Napp Pharmaceutical Holdings Limited v. Director General of Fair Trading [2002] CAT 1.

4 Case 50395 - Liothyronine tablets: suspected excessive and unfair pricing, in which a statement of objections was issued on 21 November 2017 and supplementary statements of objections were issued on 30 January 2019 and 10 July 2020; and Case 50277 - Hydrocortisone tablets: alleged excessive and unfair pricing, anti-competitive agreements and abusive con$d u c t$, in which a statement of objections were issued on 21 November 2017 and a supplementary statement of objections was issued on 12 February 2020.

5 Flynn Pharma Limited and Flynn Pharma (Holdings) Limited v. Competition and Markets Authority; Pfizer Inc and Pfizer Limited v. Competition and Markets Authority [2018] CAT 11.
6 Flynn Pharma Limited and Flynn Pharma (Holdings) Limited v. Competition and Markets Authority; Pfizer Inc and Pfizer Limited v. Competition and Markets Authority [2019] CAT 9 (Flynn and Pfizer v. CMA, CAT costs judgment).

7 Competition and Markets Authority v. Flynn Pharma Limited, Pfizer Inc \& Ors [2020] EWCA Civ 339.

8 The Court of Appeal did accept the CMA's argument that - contrary to the finding made by the CAT - the CMA is not required to identify a hypothetical benchmark price.

9 CMA v. Flynn and Pfizer, Court of Appeal costs judgment (fn 1).

10 A. Menarini Diagnostics S.r.l. v. Italy - European Court of Human Rights, Case 43509/08 (27 September 2011). 
considered by the competition authorities). All companies of all sizes (many of which do not have an inhouse legal team) are required to understand and apply competition law. Decisions interpreting the underlying legislation and applying it in practice affect companies' self-assessment of the competition law risks they face and how best to comply with their legal obligations.

The Court of Appeal's judgment also comes at a time when the use of settlement or commitment procedures to resolve CMA investigations has been steadily increasing and, as the body of established precedent grows, settlements could play an ever greater role. However, for parties to be able to decide not to dispute the CMA's legal assessment and be willing to settle on a principled basis, precedent must be sufficiently developed, clear and applicable. ${ }^{11}$ In addition, given the central role of competition law in underpinning a functioning market economy, each action taken by the CMA and the way in which it is resolved has a wider impact on perception of the system, on the economy and, ultimately, on consumers.

Much of the foregoing may appear - at least to the competition law community - to be self-evident. Yet the particular nature of competition enforcement has a significant bearing on the impact of the case under discussion in this article. Competition enforcement involves the application of legal principles which are developed substantively through an iterative, case-driven process. In stark contrast to regulatory systems - such as telecoms regulation as enforced by Ofcom in the UK the statutory provisions are brief, with the expectation that the CMA, the sectoral regulators (when exercising concurrent competition law powers), the CAT and the courts will develop the law and enable those subject to it to understand its more detailed application. Concepts such as 'hub-and-spoke' infringements ${ }^{12}$ or excessive pricing (the subject of the case at issue here) have been developed exclusively through case law, mostly based on appeals from competition authorities. ${ }^{13}$

11 Commentators have previously expressed reservations about the impact of commitment decisions on legal certainty for business, which relies on the 'equal application of generalized legal norms ... subject to oversight by courts ...': see R. Stones, 'Commitment Decisions in EU Competition Enforcement: Policy Effectiveness v. the Formal Rule of Law' (2019) 38 Yearbook of European Law 361-99.

12 Argos Limited and Littlewoods Limited v. Office of Fair Trading; JJB Sport PLC v. Office of Fair Trading [2006] EWCA Civ 1318.

13 In the field of excessive pricing, as applied in the UK, one significant case arose out of private litigation, and involved a reversal on appeal: Attheraces Ltd \& Anor v. British Horseracing Board Ltd \& Anor [2007] EWCA Civ 38 reversing Attheraces Ltd \& Anor v. British Horse Racing Board Ltd \& Anor [2005] EWHC 3015 (Ch).

14 Phenytoin itself is one such example. The CMA's predecessor was also held to have erred in its decisions on a number of occasions, including:
The CMA is expected, and undoubtedly strives, to 'get it right' when adopting infringement decisions (although does not always do $\mathrm{so}^{14}$ ), but genuine and important legal issues of general application can arise. For consistency and foreseeability, these may need to be considered by the courts. Such consistency and foreseeability is not only a hallmark of a well-functioning legal system, it is also vital for competition law to meet its goals of prohibiting anti-competitive conduct, and permitting conduct which is competitively benign, for the benefit of consumers and thus the economy as a whole.

For such consideration to take place, when appropriate, requires those to whom decisions are addressed to be prepared and able to invoke the powers of review provided by statute when a decision is unclear or appears to involve a potentially erroneous interpretation of the law. To take one example of this iterative process in action, resulting in a necessary clarification of the law, the partially successful appeal by Flynn and Pfizer in the case under discussion demonstrates a situation when the courts were required to settle the law not only for the benefit of the parties, but for clarity as to the appropriate legal test and standard of review to be applied by the competition authority when considering excessive pricing. This greater clarity will no doubt also benefit the CMA in its ongoing investigations into excessive pricing in the pharmaceutical sector, potentially reducing the risks of successful appeals in future cases.

Indeed, it is not only successful appeals that are valuable. Even appeals that are unsuccessful from the perspective of the appellant can have wider benefits if judicial scrutiny of the issues and clarification of important principles lead to better enforcement of, and compliance with, the law in future. A recent example of such a case is Ping Europe v. CMA ${ }^{15}$ in which the CAT upheld the CMA's decision that an infringement had taken place, but on a materially different basis from the rationale set out in the CMA's decision. ${ }^{16}$
(1) Imperial Tobacco Limited and Ors v. Office of Fair Trading [2011] CAT 41, in which the OFT had to concede that the restraints on competition on which it founded its defence of the appeals against its decision in Tobacco (Case CE/2596-03 Tobacco (15 April 2010)) were not contained in that decision, such that the appeals were allowed; and (2) Tesco Stores Ltd and Ors v. Office of Fair Trading [2012] CAT 31, in which the majority of the findings of a concerted practice involving Tesco in its decision in Dairy retail price initiatives (Case CE/3094-03) were set aside by the CAT.

15 Ping Europe Limited v. Competition and Markets Authority [2018] CAT 13.

16 See, in particular, Ping v. CMA (fn 15), paras 98-100. The CAT's decision was upheld by the Court of Appeal in Ping Europe Limited v. Competition and Markets Authority [2020] EWCA Civ 13. 
The need for consistency and for appropriate oversight has been a feature of EU competition law (on which current UK competition law is based) since its inception over 60 years ago. The relevance of that judicial precedent was given statutory force in section 60 of the Competition Act 1998 (CA 1998) and will be preserved (in a more limited way) following the end of the Brexit transition period by a new section $60 \mathrm{~A}$. Many CMA decisions today rely extensively on precedents developed and honed before the Luxembourg courts. The same principles have also characterized the current UK competition law regime from its formative days. OFT and CMA decisions have been scrutinized on a number of occasions by both the CAT and the Court of Appeal, leading to enhanced understanding of the application of competition law in the UK.

When consulting on the establishment of the CMA, the government highlighted the importance of accountability on the part of competition authorities for the decisions they make. ${ }^{17}$ The government also stressed that, in so far as possible given factual differences between different sectors, decisions taken by such authorities need to be consistent. ${ }^{18}$ To ensure this, the government emphasized that access to an appropriate appellate process should be available to '... all affected parties not just to the largest regulated firms with the most resources and experience .... ${ }^{19}$ Similar points emerged from parliamentary debates prior to the introduction of the Competition Act 1998: for example, in October 1997 the then Minister for the Department of Trade and Industry (Lord Simon of Highbury) noted that if the new regime is to work effectively and to command the confidence of business and consumers, it is essential that it is fair and transparent, and that there are effective rights of appeal'. ${ }^{20}$

More recently, a background note prepared by the OECD Competition Division Secretariat for an OECD
Working Party on the standard of review by courts in competition cases stated that:

Review by the courts of the enforcement of competition law helps to ensure that enforcement process and decisions follow the applicable rules, parties' rights are respected and the exercise of competition authorities' discretion is pursued within legally set bounds ${ }^{21}$

A UK contribution to the same OECD working party developed this point, stating:

The courts' rigorous oversight and review of decisions made by competition authorities, such as the CMA, is critical to the fairness and integrity of the UK's competition enforcement regime. An effective appeal mechanism, by holding competition authorities to account for their decisions, ensures that high standards of procedural fairness and analytical rigour are adhered to and thereby builds confidence in the system on the part of businesses and consumers. ${ }^{22}$

The need for an effective mechanism to appeal CMA decisions has therefore long been accepted as a part of the overall regime for effective competition law enforcement in the UK. It also appears to have been accepted that to be properly effective, such a regime must be accessible (including in view of companies' differing resources) and, by implication, must be used. Against that background, it might be suggested that anything which materially hinders meritorious appeals should be considered with caution, absent a legislative decision to change the underlying approach. Given that costs can be a consideration for parties (and not only for small undertakings ${ }^{23}$ ) deliberating whether to appeal, any decision affecting that calculus has the potential to be an important development. As explained further below, the Court of Appeal's judgment in CMA v. Flynn and Pharma has that potential. The parties are understood to have sought permission to appeal to the Supreme Court both the Court of Appeal's judgment on the merits and its judgment on costs, decisions on which are pending at the time of writing. ${ }^{24}$
17 See e.g. Department for Business, Innovation and Skills, Streamlining Regulatory and Competition Appeals - Consultation on Options for Reform (BIS/13/86, 19 June 2013), pp 4, 10, 17 and 26, available at: https:// assets.publishing.service.gov.uk/government/uploads/system/uploads/ attachment_data/file/229758/bis-13-876-regulatory-and-competitionappeals-revised.pdf (accessed 30 November 2020).

18 Streamlining Regulatory and Competition Appeals - Consultation on Options for Reform (fn 17), p 10.

19 Streamlining Regulatory and Competition Appeals - Consultation on Options for Reform (fn 17), p 4.

20 Hansard Parliamentary Reports, Volume 582 (30 October 1997), House of Lords second reading of the Competition Bill. Similar points were made on the second reading before the House of Commons; see Hansard Parliamentary Reports, Volume 312 (11 May 1998).

21 OECD Working Party No. 3 on Co-operation and Enforcement, The standard of review by courts in competition cases - Background Note
(DAF/COMP/WP3(2019)1, 4 June 2019), para 1, available at: https:// one.oecd.org/document/DAF/COMP/WP3(2019)1/en/pdf (accessed 30 November 2020).

22 The standard of review by courts in competition cases - Note by the United Kingdom (DAF/COMP/WP3/WD(2019)20, 4 June 2019, para 12, available at: https://one.oecd.org/document/DAF/COMP/WP3/WD(2019)20/en/ pdf (accessed 30 November 2020).

23 In the context of particular cases, important issues of legal principle may sometimes have limited immediate monetary value to the individual companies involved, and when deciding whether to appeal, the potential costs implications may play a role in decision making.

24 Bristows LLP acts for a non-party that has made submissions to the Supreme Court in support of granting permission to appeal the Court of Appeal's decision on costs. 


\section{The relevant rules on costs and the CAT's past practice}

Under rule 104(2) of the Competition Appeal Tribunal Rules 2015, the CAT has the discretion to 'make any order it thinks fit in relation to the payment of costs in respect of the whole or part of the proceedings'. That discretion has previously been described by the Court of Appeal as being 'wide and general'. ${ }^{25}$ Factors that may be taken into account are listed in rule 104 (4), and include 'whether a party has succeeded on part of its case, even if that party has not been wholly successful'. Paragraph 8.6 of the CAT's Guide to Proceedings refers to several cases that are considered to provide a useful overview of the CAT's approach to costs. ${ }^{26}$ For appeals of competition law decisions under Chapters I and II of the CA 1998, the CAT operates under its own rules, rather than under the Civil Procedure Rules (CPR) which apply in civil litigation between private parties in the English Courts. ${ }^{27}$ Nevertheless, the CAT's practice to date has been to adopt a starting point which is in line with the general rule at CPR 44.2(2)(a) that costs follow the event, i.e., the unsuccessful party will pay the costs of the successful party.

As in the wider civil jurisdiction, this general approach can serve to ensure proper consideration of the merits before pursuing any action, and should encourage parties to focus on only their strongest claims or arguments. When conducting a review of civil litigation costs, Lord Justice Jackson explained the rule's purpose as 'a mechanism to encourage appropriate behaviour on all sides for the benefit of the court and dispute resolution generally'. ${ }^{28}$ It also has an element of natural fairness; a party should not be required to bear the burden of costs when a court has adjudicated a matter in their favour. As summarized by Lord Justice Jackson, while the rule is recognized not to be an immutable one, it does ensure effective access to justice for claimants, but deters unmeritorious claims and provides a reasonable measure of indemnification for defendants which have been vindicated. ${ }^{29}$

25 Judgment of Lord Justice Lloyd, Quarmby Construction Company v. Office of Fair Trading [2012] EWCA Civ 1552, para 12

26 CAT Guide to Proceedings (2015), available at: https://www.catribunal.org. uk/sites/default/files/2017-12/guide_to_proceedings_2015.pdf (accessed 30 November 2020).

27 The non-applicability of the Civil Procedure Rules to CAT proceedings has previously been confirmed by the Court of Appeal. Quarmby Construction $v$. OFT (fn 25), para 23.

28 Lord Justice Jackson, Review of Civil Litigation Costs: Preliminary Report, Volume 2 (May 2009), p 469, available at: https://www.judiciary.uk/wpcontent/uploads/JCO/Documents/Guidance/jackson-vol2-low.pdf (accessed 30 November 2020)
In deciding whether to appeal CMA decisions, addressees will need to consider not only the merits, but also the risks of where costs may fall. In certain instances - particularly when a smaller company is involved - the costs of appealing may exceed any penalty amount. While that might be less likely to deter an appeal where costs recovery from the CMA is potentially available, it is much more likely to do so if the starting position is that costs should not be recovered (subject to other considerations around the impact of the decision on the addressee's day-to-day business, and other factors such as director disqualifications arising out of the case). The fact that costs are assessed only at the end of the proceedings means that even if there is in principle a willingness on the part of the CAT to take a different approach in some cases, such as in cases where the appellant is impecunious, this will not be known until the costs have been incurred. Even cases involving lower fines or smaller companies may still raise issues of general importance. Leaving such decisions unappealed risks influencing the conduct of others on the market.

The potential for asymmetry between the successful appellant's inability to recover costs from the CMA and the CMA's right to claim costs against the appellant if the appeal is unsuccessful skews the position still further. The Court of Appeal judgment in Flynn and Pfizer did not address the ability of the CMA to recover its costs from an addressee in the event of a successful defence of its decision. At present, the position on that front therefore remains unchanged, so the CAT may award the CMA its costs if its decision is upheld, in line with its previous practice. ${ }^{30}$ The CMA certainly has an incentive to continue to seek to recover its costs, which, in Pfizer and Flynn's appeal of the Phenytoin decision before the CAT amounted to nearly $£ 1.9$ million. ${ }^{31}$ While the Court of Appeal expressly left open the possibility that the CAT may alter its previous practice in order to maintain a symmetric approach, ${ }^{32}$ any such decision is likely to be contested by the CMA, including in all likelihood on appeal to the Court of Appeal and potentially beyond, resulting in
29 Review of Civil Litigation Costs: Preliminary Report (fn 28), p 469.

30 For example, the CMA was recently granted its costs in Ping Europe Limited v. CMA [2019] CAT 6, despite the CAT's view that the CMA had erred in law in certain respects. The CMA's supplemental skeleton for its appeal to the Court of Appeal (cited in CMA v. Flynn and Pfizer, Court of Appeal Costs Judgment (fn 1), para 101) made clear that the issues for consideration by the Court of Appeal did not include whether the CMA can recover its costs when it succeeds.

31 Flynn and Pfizer v. CMA, CAT costs judgment (fn 6), para 21.

32 CMA v. Flynn and Pfizer, Court of Appeal Costs Judgment (fn 1), para 102 . 
yet greater costs risk for the opposing party in the case in which this issue comes up.

There is always a balance to be struck in any competition law regime between measures designed to avoid false positives (incorrectly identified infringements) and those intended to reduce false negatives (failing to sanction breaches of competition law). A new systemic bias towards false positives could ultimately harm that balance. While there is no perfect position, and different legal regimes take different views on the appropriate balance between false positives and false negatives, it seems counterintuitive to take a risk that such an important policy matter should be decided by a shift in how costs are dealt with. ${ }^{33}$

\section{The award of costs against the CMA by the CAT in this case}

As mentioned above, Pfizer and Flynn had been partially successful before the CAT, persuading the CAT that the CMA's findings on abuse were unsafe and should be remitted.

Pfizer sought an order that the CMA should pay all of its costs (estimated at up to $£ 4.7$ million), with an interim payment of $£ 1.3$ million if the CAT was minded to order a detailed assessment. ${ }^{34}$ Flynn also sought an order that the CMA pay its costs (amounting to around $£ 3$ million), with an interim payment of $£ 1.5$ million pending a detailed assessment. ${ }^{35}$ Both argued that they were entitled to costs as they were the successful party overall, and the CMA had lost; it was argued that although the dominance part of the CMA's decision had not been overturned, the consequence of setting aside the findings of abuse meant the CMA had lost overall as its decision could not stand.

The CMA asked the Tribunal to reserve the issue of costs until after the final determination of any appeals, or alternatively, make no order for costs (as there was no overall 'winner'), save in respect of Pfizer's and Flynn's unsuccessful applications for interim measures; in the further alternative, it argued that the CMA should

33 The appropriate balance and the role of competition law enforcement more generally is currently a matter of active policy and political debate. As well as specific considerations around the digital sector, recent initiatives have included the intervention of the then CMA Chair Lord Tyrie calling for an end to full merits appeals of CMA decisions and its replacement with a new standard of review (letter to the Secretary of State for Business, Energy and Industrial Strategy, 21 February 2019, available at: https://assets.publishing.service.gov.uk/government/uploads/system/ uploads/attachment_data/file/781151/Letter_from_Andrew_Tyrie_ to_the_Secretary_of_State_BEIS.pdf (accessed 30 November 2020)) and the subsequent appointment of John Penrose MP to review enhancements to the UK's competition law regime (see HM Treasury press release, John Penrose MP to lead review exploring how to bolster UK competition policy (14 September 2020)). For an alternative perspective on Lord Tyrie’s calls for reform, see M. Friend, 'Are competition appeals taking too long?' make an issue-based costs order, distinguishing between the questions of market definition and dominance (where the CMA had successfully defended its decision) and the abuse findings. In relation to the findings of abuse, where Pfizer and Flynn had succeeded before the CAT, leading to the remittal decision, the CMA submitted that it defended the appeals pursuant to its statutory duties and its actions were reasonable, so the starting point for any costs against it should be no order for $\operatorname{costs}^{36}$ in accordance with BT $v$. Ofcom. ${ }^{37}$

The CAT confirmed that, despite the absence of a rule equivalent to CPR 44.2(2) (which applies in civil proceedings before the courts of England and Wales), its practice had nonetheless been to adopt that general rule as the starting point in appeals against decisions concerning Chapter I or Chapter II of the CA 1998 (and/or Article 101 or 102 TFEU). ${ }^{38}$ It referred to The Racecourse Association v. OFT ${ }^{39}$ for a summary of the general approach:

First, as in all cases, there is no immutable rule as to the appropriate costs order; and how the discretion will be exercised in any case will depend on its particular circumstances, one relevant consideration being whether any award of costs may be perceived as frustrating the objects of the Act. Second, subject to this, the starting point is that a successful appellant who can fairly be identified as a "winner" is entitled to recover his costs. Third, such an appellant will not necessarily be entitled to recover all his costs, and may in particular be deprived of those costs referable to issues on which he has failed, or which were not germane to the Tribunal's decision, or which involved unnecessary prolixity or duplication, and he may suffer a partial or total disallowance of costs by reason of any unreasonable conduct on his part. Fourth, the OFT is not entitled to any special protection from vulnerability to costs orders in favour of successful appellants save such protection as it may obtain by appropriate case management of the appeal directed at ensuring that the costs of the appeal are kept within proportionate bounds.

Having set out the basic position, the CAT recognized that the Court of Appeal's judgment in BT v. Ofcom ${ }^{40}$ 'may cast some doubt on the general approach hitherto adopted by the Tribunal'. ${ }^{41}$

Oxera Agenda (February 2020), available at: https://www.oxera.com/ agenda/are-competition-appeals-taking-too-long/ (accessed 30 November 2020).

34 Flynn and Pfizer v. CMA, CAT costs judgment (fn 6), paras 18-20.

35 Flynn and Pfizer v. CMA, CAT costs judgment (fn 6), paras 18-20.

36 Flynn and Pfizer v. CMA, CAT costs judgment (fn 6), paras 21-25.

37 British Telecommunications plc v. The Office of Communications [2018] EWCA Civ 2542.

38 Flynn and Pfizer v. CMA, CAT costs judgment (fn 6), para 7.

39 The Racecourse Association v. Office of Fair Trading [2006] CAT 1, para 10.

40 [2018] EWCA Civ 2542.

41 Flynn and Pfizer v. CMA, CAT costs judgment (fn 6), para 9 
Both Pfizer and Flynn had submitted that the Court of Appeal's judgment in BT v. Ofcom could and should be distinguished as the circumstances in that case were different. They argued that the BT $v$. Ofcom judgment dealt with a situation where a regulatory body was obliged to act in accordance with a duty to regulate. They argued that, as a matter of substance, that was different from an infringement decision by the CMA acting as a competition authority where it was not enforcing a regulatory regime but had decided to investigate. ${ }^{42}$ In the event that BT v. Ofcom did apply, both Pfizer and Flynn claimed that the CMA had in any event acted unreasonably during the investigation and so they should still be entitled to their costs. The CMA submitted that BT v. Ofcom required the CAT to reconsider its approach to costs against a public authority that was defending a decision in the public interest, and that it should therefore adopt a starting point that there should be no order that the CMA should pay the appellants' costs. ${ }^{43}$

In coming to a decision, the CAT first found no reason to depart from its usual practice of deciding costs when appeals are in progress, nor any reason not to make a costs award. ${ }^{44}$ It then considered what the correct starting point should be, following the parties' submissions on the application of BT $v$. Ofcom. The CAT defined the issue as 'whether a competition infringement case decided by the CMA is a "similar regulatory situation" to that in which Ofcom was discharging its regulatory functions in the manner considered by the Court of Appeal in BT v. Ofcom' ${ }^{45}$

Although the CAT considered that some of the statements of the Court of Appeal in BT v. Ofcom were capable of applying in the context of competition enforcement, it found that the specific issue of competition enforcement as part of the wider context was not addressed in the judgment. In those circumstances, the CAT noted its expectation that had the Court of Appeal actually considered the issue and intended its decision to apply in competition law cases, there would have been a clearer conclusion to that effect. ${ }^{46}$

The CAT therefore proceeded to consider whether an appeal of an infringement decision by the CMA is in fact a 'regulatory situation' of the sort explicitly dealt with by the Court of Appeal. The parties' arguments on this issue focused on the CMA's statutory duties and the extent of its discretion to pursue an investigation under the CA 1998. Pfizer also claimed a further difference was relevant; the CMA's extensive powers and resulting substantial penalty of a quasi-criminal nature. ${ }^{47}$

The CAT described an appeal from a CMA decision on competition law infringement as:

... not just a review or endorsement of what the CMA has done. The appeal to the Tribunal is the parties' first opportunity to put their case to an independent and impartial appeal body and for the CMA to defend its decision. It is an appeal 'on the merits'. It is thus an essential part of the system by which competition authorities, in return for receiving extensive enforcement powers, are held to account by the courts.

Such a competition appeal therefore appears to us to have significant differentiating characteristics from the application of the regulatory regime for communications, or a market investigation ..... ${ }^{48}$

The CAT therefore concluded that it was not required to depart from its established practice and extend the decision in BT v. Ofcom more widely than was expressly articulated by the Court of Appeal. ${ }^{49}$ It found that the CMA had not acted unreasonably, unfairly or in bad faith in pursuing its investigation or defending its decision, and that neither party had claimed that its costs had caused financial hardship. ${ }^{50}$

Having decided the point of principle, that its starting point in assessing costs was that costs should follow the event, ${ }^{51}$ the CAT ultimately found it appropriate to award costs on a basis that reflected the overall level of success of each party. ${ }^{52}$ Thus, the CMA would be awarded its costs of defending Pfizer's and Flynn's claims in respect of market definition and dominance (on which it was successful) and Pfizer and Flynn would be awarded a proportion of their costs in respect of abuse (in which they were in part successful); onethird of total costs related to market definition and dominance and two-thirds to abuse. ${ }^{53}$ Some of Pfizer's and Flynn's specific costs were disallowed as being disproportionate. ${ }^{54}$

In assessing the basis on which costs were ultimately to be recoverable (following a detailed assessment), the CAT agreed with the CMA's submission that while appellants are 'free to spend whatever they wish in
42 Flynn and Pfizer v. CMA, CAT costs judgment (fn 6), paras 15-17 and 20.

43 Flynn and Pfizer v. CMA, CAT costs judgment (fn 6), paras 23-25.

44 Flynn and Pfizer v. CMA, CAT costs judgment (fn 6), paras 26-29.

45 Flynn and Pfizer v. CMA, CAT costs judgment (fn 6), paras 30 and 31.

46 Flynn and Pfizer v. CMA, CAT costs judgment (fn 6), paras 32-34.

47 Flynn and Pfizer v. CMA, CAT costs judgment (fn 6), paras 35-46.

48 Flynn and Pfizer v. CMA, CAT costs judgment (fn 6), paras 43-44.

49 Flynn and Pfizer v. CMA, CAT costs judgment (fn 6), para 46.
50 Flynn and Pfizer v. CMA, CAT costs judgment (fn 6), paras 49-51.

51 Flynn and Pfizer v. CMA, CAT costs judgment (fn 6), para 52.

52 Flynn and Pfizer v. CMA, CAT costs judgment (fn 6), paras 53-57.

53 Flynn and Pfizer v. CMA, CAT costs judgment (fn 6), paras 64-67; Pfizer and Flynn were held to each be liable for $50 \%$ of the CMA's costs: Flynn and Pfizer v. CMA, para 66.

54 Flynn and Pfizer v. CMA, CAT costs judgment (fn 6), paras 58-63. 
bringing their appeals, it does not follow that the CMA should be required to bear the full burden of their legal costs out of public funds'. ${ }^{55}$ However, the CAT did stay its order until the Court of Appeal had ruled on the parties' appeals. ${ }^{56}$ It also accepted that, given the way in which $B T v$. Ofcom had been dealt with by the Court of Appeal, the CMA should be granted permission to appeal the CAT's costs ruling to the Court of Appeal. ${ }^{57}$

\section{The Court of Appeal's ruling on costs}

Unsurprisingly, given the circumstances and the wider implications of the issue, the CMA challenged the CAT's conclusions as to the correct starting point for a costs award. It argued that the correct starting point when considering whether to award costs against a public body performing its functions in the public interest should be no order for costs, unless there is good reason (such as unreasonable conduct, or financial hardship) to do so. ${ }^{58}$ The CMA relied on four decided cases, but $B T v$. Ofcom was again a focus.

Lord Justice Lewison (with whom Floyd and Arnold LJJ agreed) delivered the leading judgment in the Court of Appeal. Having reviewed the authorities, he considered that in BT v. Ofcom the Court of Appeal intended its decision to apply to 'merits appeals', the case before it being such an appeal (even if not an infringement case) and thus rejected the proposition that costs follow the event in CAT merits and judicial review appeals. ${ }^{59}$ In exercising a discretion on awarding costs when one party is a regulator exercising functions in the public interest, 'the starting point or default position is that no order for costs should be made against a regulator who has brought or defended proceedings in the CAT acting purely in its regulatory capacity', which may be departed from for 'good reason', e.g. unreasonable conduct or substantial financial hardship. ${ }^{60}$ Accordingly, the CAT had misunderstood BT v. Ofcom and had been wrong to conclude that, in $B T v$. Ofcom the Court of Appeal would have expressly mentioned appeals of competition infringement decisions if it had intended them to be covered by the rule set out by it in that

\footnotetext{
55 Flynn and Pfizer v. CMA, CAT costs judgment (fn 6), para 68.

56 Flynn and Pfizer v. CMA, CAT costs judgment (fn 6), paras 89-92.

57 Flynn Pharma Limited and Flynn Pharma (Holdings) Limited v. Competition and Markets Authority; Pfizer Inc and Pfizer Limited v. Competition and Markets Authority (Permission to Appeal: Costs) [2019] CAT 16.

58 CMA v. Flynn and Pfizer, Court of Appeal costs judgment (fn 1), para 5.

59 CMA v. Flynn and Pfizer, Court of Appeal costs judgment (fn 1), paras 74 and 75 .

60 CMA v. Flynn and Pfizer, Court of Appeal costs judgment (fn 1), para 79.

61 CMA v. Flynn and Pfizer, Court of Appeal costs judgment (fn 1), para 83.
}

case. On the contrary, he considered that the court would have expressly excluded such appeals from the rule laid down by it if that had been its intention. ${ }^{61}$ This is a somewhat curious finding, given that any discussion of competition infringement appeals by the Court of Appeal in BT v. Ofcom would necessarily have been obiter. ${ }^{62}$

Instead the Court of Appeal held that the correct default position is that a regulator (including the CMA) defending a regulatory or administrative decision adopted in the exercise of its functions in the public interest should not be subject to adverse costs orders in the CAT merely because it was unsuccessful. ${ }^{63}$

In addressing the parties' arguments in its judgment, the Court of Appeal considered three main points:

1. precedent case law concerning costs awards against regulatory bodies;

2. the applicable legal principles and their application to the present case; and

3. additional arguments made by Pfizer and Flynn.

\subsection{Precedent case law}

Before the Court of Appeal, the CMA relied principally on three cases decided before BT v. Ofcom.

Bradford MDC v. Booth ${ }^{64}$ was the first building block of the CMA's case. That case concerned a decision by a local council not to renew a private hire licence, a decision which was overturned on appeal. The magistrates hearing the case had a discretion to make such order for costs as was 'just and reasonable' and made an award to the taxi driver. On appeal by way of case stated, the Magistrates asked the Divisional Court to determine whether the principle that 'costs follow the event' applies against local authorities when making decisions on the licensing functions that they are required to perform. The council argued that it can never be just and reasonable to order a local authority to pay costs in the absence of bad faith or unreasonable behaviour', ${ }^{65}$ but that submission was rejected because it 'would deprive the magistrates of their discretion to view matters in the round'. ${ }^{66}$ The Court of Appeal therefore found that Bradford did not directly support the CMA's proposition

62 Lewison LJ did recognize as a general matter that this finding in $B T v$. Ofcom was obiter and not directly binding on the CAT in CA 1998 appeals, but considered that it had intended to give the CAT general guidance: CMA v. Flynn and Pfizer, Court of Appeal costs judgment (fn 1), para 75.

63 CMA v. Flynn and Pfizer, Court of Appeal costs judgment (fn 1), paras 8891.

64 Bradford MDC v. Booth (2000) 164 JP 485.

65 Bradford MDC v. Booth (fn 64), para 10.

66 Bradford MDC v. Booth (fn 64), para 22. 
that the starting point should be no order as to costs, ${ }^{67}$ but did observe that the termination of a licence to carry out a business had an even more profound impact than a competition infringement decision may have upon a business, ${ }^{68}$ and noted that the encouragement of public authorities to make and stand by decisions is merely a factor to be considered when making a costs award. ${ }^{69}$

Other cases considered by the Court provided somewhat more support for the CMA's proposition. One case, Baxendale-Walker v. Law Society, arose in the context of a costs award against the Law Society in disciplinary proceedings before the Solicitors Disciplinary Tribunal. The Divisional Court held that a costs order should not be made against the Law Society when discharging its responsibilities as a regulator unless there is a good reason to do so, and that that reason must be more than mere success (although success is one factor for consideration)..$^{70}$ The Court of Appeal did not consider the differences between the type of regulatory regime operated by the Law Society (which applies to a class of professionals in the way they carry out their duty) and the nature of competition law which applies as primary law to all undertakings involved in economic activity, but confirmed that it endorsed the starting point or 'default position' for which the CMA was advocating. ${ }^{71}$

The earlier Court of Appeal judgment in BT v. Ofcom formed the lynchpin of the Court's reasoning. ${ }^{72}$ That case also involved an appeal of a CAT ruling that costs 'followed the event', in the context of a regulatory appeal by way of judicial review, in which the CAT had quashed part of the regulator's decision, under the Communications Act 2003 that BT had market power and should therefore be subject to economic regulation in the wholesale supply of leased lines. ${ }^{73}$ In CMA v. Flynn and Pfizer, the Court of Appeal noted that BT v. Ofcom involved a 'merits appeal' against Ofcom's decision. ${ }^{74}$ This was contrasted with cases (such as the resolution of pricing disputes) where the CAT's practice was that there should be no order as to costs against Ofcom unless it had acted reasonably and in good faith. ${ }^{75}$ The Court of Appeal, reiterating its previous position in $B T \nu$. Ofcom, saw this contrast as a 'distinction without a difference', ${ }^{76}$ and concluded that 'this court has comprehensively rejected the proposition that the starting point, even in a merits or judicial review appeal in the CAT, is that costs follow the event'. ${ }^{77}$ Even if the Court of Appeal was not technically bound by its earlier judgment, it considered that it was a case that it nevertheless ought to follow. ${ }^{78}$

\subsection{Legal principles and their application}

The Court derived six principles from the case law: ${ }^{79}$

1. The fact that one of the parties is a regulator exercising functions in the public interest is an important factor in exercising discretion as to costs.

2. The default position is that no order for costs should be made against a regulator acting purely in its regulatory capacity.

3. The default position may be departed from for good reason.

4. A regulator merely being unsuccessful is not sufficient, but it is not necessary to find 'exceptional circumstances'.

5. Good reason will include unreasonable conduct by the regulator, or the likelihood of the successful party suffering substantial financial hardship.

6. There may be additional factors specific to the particular case which may permit a departure from the starting point.

Unlike the CAT, the Court of Appeal did not find the CMA's discretion to take on cases and to adopt an infringement decision of critical importance; nor did it find the quasi-criminal nature of a Competition Act penalty compelling. ${ }^{80}$ An appeal to the CAT is a 'merits appeal', and the CMA's role in that instance is described as defending a regulatory or administrative decision. ${ }^{81}$ The appeal in BT v. Ofcom was also a merits appeal, so the Court of Appeal held that this was also not a ground of distinction. ${ }^{82}$

The Court of Appeal therefore found that the CAT had misinterpreted BT v. Ofcom, and that the reasons
67 CMA v. Flynn and Pfizer, Court of Appeal costs judgment (fn 1), para 22.

68 CMA v. Flynn and Pfizer, Court of Appeal costs judgment (fn 1), para 89. This opinion diverged from the view of the CAT in Tesco plc v. Competition Commission [2009] CAT 26, para 32, where the CAT stated that 'Such licensing cases are different in nature from an application for judicial review, which concerns the lawfulness or validity of the decision being challenged'.

69 CMA v. Flynn and Pfizer, Court of Appeal costs judgment (fn 1), para 22.

70 Baxendale-Walker v. Law Society [2007] EWCA Civ 233.

71 CMA v. Flynn and Pfizer, Court of Appeal costs judgment (fn 1), paras 8890.

72 BT v. Ofcom (fn 37).

73 British Telecommunications plc v. Office of Communications (Market definition) [2017] CAT 25.
74 CMA v. Flynn and Pfizer, Court of Appeal costs judgment (fn 1), paras 63 76.

75 See e.g. The Number (UK) Ltd v. Ofcom (Costs) [2009] CAT 5, paras 5 and 6.

76 CMA v. Flynn and Pfizer, Court of Appeal costs judgment (fn 1), para 70, referring to $B T$ v. Ofcom (fn 37), para 75.

77 CMA v. Flynn and Pfizer, Court of Appeal costs judgment (fn 1), para 75.

78 CMA v. Flynn and Pfizer, Court of Appeal costs judgment (fn 1), para 76.

79 CMA v. Flynn and Pfizer, Court of Appeal costs judgment (fn 1), para 79.

80 CMA v. Flynn and Pfizer, Court of Appeal costs judgment (fn 1), paras 88 and 89.

81 CMA v. Flynn and Pfizer, Court of Appeal costs judgment (fn 1), para 74.

82 CMA v. Flynn and Pfizer, Court of Appeal costs judgment (fn 1), para 75 
for distinguishing competition infringement cases were not compelling. The court held, in particular, that the CAT did not appear to have given any weight to the position of the CMA as a public authority carrying out its functions in the public interest. ${ }^{83}$

In fact, the CAT did, as noted above, ${ }^{84}$ comment on the quantum of costs that it is appropriate to award against a body carrying out 'public functions'. The Court of Appeal's judgment does not address this point directly, preferring a wholesale change to the starting point for the award of costs. Whilst the Court noted that success or failure is still relevant (and is expressly referred to in CAT rule 104), that is not the sole or primary basis on which any costs award is to be premised. ${ }^{85}$ In particular, the question of financial hardship to a successful appellant is a relevant factor, ${ }^{86}$ although the Court of Appeal did not consider whether this requires evidence of impecuniosity or a lower standard, such as the impact on a business of diverting funds away from commercial activities. A more recent judgment in the High Court notes the particular need not to expose defendants to 'excessive' cost when defending cases brought by regulators - who are required to exercise their powers proportionately. ${ }^{87}$

\subsection{Additional arguments made by Pfizer and Flynn}

Pfizer and Flynn had 'emphasised the contribution of "costs follow the event" to discipline in litigation' ${ }^{88}$ Indeed, it is readily understood in litigation that costs implications can focus the parties on their most viable arguments, avoiding a 'kitchen sink' approach that can both waste court time and unfairly pressure a party into submission. However, the Court noted that is a discipline that applies to all forms of litigation, including when the starting point is no order as to costs. ${ }^{89}$

The parties all raised the wider implications of adopting any particular starting point for costs assessment. The Court of Appeal's judgment focuses on the potential impact on the CMA but, given the past practice of the CAT in allowing costs awards against the CMA and

83 CMA v. Flynn and Pfizer, Court of Appeal costs judgment (fn 1), para 91. 84 See Section 5 and the text accompanying fn 55 above.

85 CMA v. Flynn and Pfizer, Court of Appeal costs judgment (fn 1), para 92.

86 CMA v. Flynn and Pfizer, Court of Appeal costs judgment (fn 1), paras 92, 106 and 107. The Court of Appeal considered that this could be relevant if the CMA were to pursue a small or medium-sized enterprise as a test case or where a party has borne considerable irrevocable costs at the administrative stage of the CMA's investigation.

87 Judgment of the High Court (on appeal from the Solicitors Disciplinary Tribunal) in Beckwith v. Solicitors Regulation Authority [2020] EWHC 3231 (Admin), para 58. In full: 'Regulators pursue disciplinary proceedings in the public interest; the costs they incur should reflect that the CMA's continued appetite for defending appeals, it is difficult to say that any such impact has arisen in practice. Of greater concern is the potential 'chilling effect' that any changes to the determination of costs could have on addressees of a decision. Of course, this theoretical 'chilling effect' needs to be balanced with the public interest in encouraging regulators to investigate and take decisions without undue pressure: this is part of the overall policy dilemma of balancing potential overenforcement and potential under-enforcement that all competition regimes need to address. Here, the Court of Appeal has tipped that balance towards the regulator, although it stated that the CAT can, 'if it chooses, consider whether the potential exposure to a liability for costs would deter appeals by some or all undertakings..$^{90}$

In his very short concurring judgment, Lord Justice Arnold suggested that there may be merit in the issue of appropriate costs recovery regimes against a public body being considered by the Law Commission, recognising the potential wider importance of the issue. ${ }^{91}$ While the Law Commission would be well placed to consider the broader questions relating to public bodies, the issue in this case and its wider implications may receive attention more quickly if the UK Supreme Court grants Pfizer and Flynn permission to appeal. As at the time of writing, no decision had been taken on whether to grant permission to appeal, but one significant consideration in favour is that even if there were to be a broad review by a body such as the Law Commission, timeliness on the specific issue is particularly important given the increased pace of CMA enforcement action and the potential for an increase in the number of CMA investigations (including in the field of merger control) and enforcement action following the end of the transition period for the UK's departure from the European Union, which would likely lead to an increase in appeals to the CAT.

\section{Concluding comments}

In the hearing before the Court of Appeal, all parties warned that adopting a particular starting point for an

responsibility. This is no more than one aspect of an imperative that applies to all regulators - they must exercise their regulatory powers proportionately. Since the SRA will not in the ordinary course, be required to pay costs when regulatory proceedings are successfully defended ... it must conduct its cases with proper regard to the need to permit persons who face regulatory complaints to defend themselves without excessive cost. This is part of any regulator's responsibilities in the public interest.'

88 CMA v. Flynn and Pfizer, Court of Appeal costs judgment (fn 1), para 98.

89 CMA v. Flynn and Pfizer, Court of Appeal costs judgment (fn 1), para 98.

90 CMA v. Flynn and Pfizer, Court of Appeal costs judgment (fn 1), paras 99-102.

91 CMA v. Flynn and Pfizer, Court of Appeal costs judgment (fn 1), para 110. 
award of costs could potentially give rise to a 'chilling effect'. It was generally accepted that effective competition investigations are crucial to competition policy, but the result must be 'right' for businesses, consumers and the economy as a whole. Pfizer and Flynn (as respondents to the CMA's appeal) argued that judicial scrutiny, particularly by the CAT, provides important oversight for the benefit of the companies under investigation, others active on the market, consumers and the competition authority itself. This underlying point has been clearly articulated by Peter Freeman (a Chairman of the CAT and the former Chairman of the Competition Commission):

It is an effective appeals system that provides the glue holding the whole system together and enables the system to work effectively. Weaken it or take it away and the concentration of power in the hands of the competition authorities becomes a serious concern. ${ }^{92}$

Measures which may prevent the bringing of a meritorious appeal can be of significant concern, a position which was made clear by the government, when commenting on reforms to the CAT's Rules of Procedure:

The competition regime exists to ensure competition and markets works well for consumers and business. Independent regulators and competition authorities are an essential element of this regime. However, where decisions have been delegated to independent experts outside of direct ministerial control, firms need to have a mechanism for challenging regulatory decisions, in order to correct regulatory mistakes and ensure regulators are operating in a reasonable and consistent way. Appeals are thus central to ensuring proper accountability of these bodies and well-functioning markets. The CAT plays a key role in this appeals process. ${ }^{93}$

92 P. Freeman, Appeals in Competition Infringement cases, speech at the Concurrences Conference - Innovation Economics for Antirust Lawyers 2019 (1 March 2019), available at: https://www.catribunal.org.uk/sites/default/ files/2019-03/Innovation\%20Economics\%20for\%20Antitrust\%20Lawyers. pdf (accessed 30 November 2020).

93 Impact Assessment, The Competition Appeal Tribunal (CAT) Rules 2015, pp 3-4, available at: https://assets.publishing.service.gov.uk/government/ uploads/system/uploads/attachment_data/file/458998/BIS-15-358-CATrules-2015-final-stage-impact_assessment.pdf (accessed 30 November
In the view of the authors, there appears to be a real risk that the Court of Appeal's alteration to the starting point for costs for such appeals (which are often much more costly than appeals before other tribunals, such as the Employment Appeals Tribunal, where costs awards are not usually made) could have a chilling effect on parties' appetite for appealing competition infringement decisions. The Court of Appeal acknowledged that significant financial hardship suffered by a successful appellant may be a reason to make a costs order against the CMA, ${ }^{94}$ and particularly noted this point in connection with individual directors that may be a party to an appeal of a competition infringement decision as part of a defence against disqualification proceedings. ${ }^{95}$ Although this appears to be a gesture towards reassuring less well-funded parties or individuals that they will not be left significantly out of pocket in the event of success, the lack of certainty as to what constitutes 'financial hardship' may make this reassurance ineffectual. Further, some may question whether costs awards should be based purely on grounds of financial capability. A large company with significant assets may be more capable of absorbing the costs of litigation than (for example) an SME, but at what opportunity cost?

Whatever the rights and wrongs of such considerations, the more fundamental point remains the concern that the costs asymmetry which currently results from the Court of Appeal's judgment - where the CMA will usually recover costs of defending an unsuccessful appeal, whereas a successful appellant will usually not do so - impede the appropriate further development of competition law through the court review of CMA decisions.
2020). See also Government Response: Competition Appeal Tribunal (CAT) Rules of Procedure, September 2015 available at: https://assets. publishing.service.gov.uk/government/uploads/system/uploads/attachment_ data/file/460442/BIS-15-357-competition-appeal-tribunal-rules-of-proceduregovernment-response.pdf (accessed 30 November 2020).

94 CMA v. Flynn and Pfizer, Court of Appeal costs judgment (fn 1), paras 79, 92, 93(iv) and 106

95 CMA v. Flynn and Pfizer, Court of Appeal costs judgment (fn 1), para 93(ii). 